\title{
Biased Agonism of Three Different Cannabinoid Receptor Agonists in Mouse Brain Cortex
}

\begin{abstract}
Rebeca Diez-Alarcia ${ }^{1,2}$, Inés Ibarra-Lecue ${ }^{1}$, Ángela P. Lopez-Cardona ${ }^{3,4}$, Javier Meana ${ }^{1,2}$, Alfonso Gutierrez-Adán ${ }^{3}$, Luis F. Callado ${ }^{1,2}$, Ekaitz Agirregoitia ${ }^{5}$ and Leyre Urigüen ${ }^{1,2 *}$

${ }^{1}$ Department of Pharmacology, University of the Basque Country UPV/EHU, Leioa, Spain, ${ }^{2}$ Centro de Investigación Biomédica en Red de Salud Mental, Madrid, Spain, ${ }^{3}$ Department of Animal Reproduction, Instituto Nacional de Tecnología Agraria y Alimentaria, Madrid, Spain, ${ }^{4}$ G.I. Biogénesis, Universidad de Antioquia, Antioquia, Colombia, ${ }^{5}$ Department of Physiology, University of the Basque Country, Leioa, Spain
\end{abstract}

Cannabinoid receptors are able to couple to different families of $G$ proteins when activated by an agonist drug. It has been suggested that different intracellular responses may be activated depending on the ligand. The goal of the present study was to characterize the pattern of $\mathrm{G}$ protein subunit stimulation triggered by three different cannabinoid ligands, $\Delta^{9}-\mathrm{THC}$, WIN55212-2, and ACEA in mouse brain cortex. Stimulation of the $\left[{ }^{35} \mathrm{~S}\right] \mathrm{GTP} \gamma \mathrm{S}$ binding coupled to specific immunoprecipitation with antibodies against different subtypes of $G$ proteins $\left(G \alpha_{i 1}, G \alpha_{i 2}, G \alpha_{i 3}, G \alpha_{0}, G \alpha_{z}, G \alpha_{s}\right.$, $\mathrm{G} \alpha_{\mathrm{q} / 11}$, and $\mathrm{G} \alpha_{12 / 13}$ ), in the presence of $\Delta^{9}$-THC, WIN55212-2 and ACEA (submaximal concentration $10 \mu \mathrm{M}$ ) was determined by scintillation proximity assay (SPA) technique in mouse cortex of wild type, $\mathrm{CB}_{1}$ knock-out, $\mathrm{CB}_{2}$ knock-out and $\mathrm{CB}_{1} / \mathrm{CB}_{2}$ double knock-out mice. Results show that, in mouse brain cortex, cannabinoid agonists are able to significantly stimulate not only the classical inhibitory $\mathrm{G} \alpha_{\mathrm{i} / \mathrm{o}}$ subunits but also other $\mathrm{G}$ subunits like $\mathrm{G} \alpha_{z}, \mathrm{G} \alpha_{\mathrm{q} / 11}$, and $\mathrm{G} \alpha_{12 / 13}$. Moreover, the specific pattern of $\mathrm{G}$ protein subunit activation is different depending on the ligand. In conclusion, our results demonstrate that, in mice brain native tissue, different exogenous cannabinoid ligands are able to selectively activate different inhibitory and non-inhibitory Ga protein subtypes, through the activation of $\mathrm{CB}_{1}$ and/or $\mathrm{CB}_{2}$ receptors. Results of the present study may help to understand the specific molecular pathways involved in the pharmacological effects of cannabinoid-derived drugs.

Keywords: $\mathrm{CB}_{1}$ receptor, $\mathrm{CB}_{2}$ receptor, functional selectivity, scintillation proximity assay (SPA), $\mathrm{G}$ proteins, brain

\section{INTRODUCTION}

During the last decade a wide number of studies have focused on the potential involvement of the endocannabinoid system in a variety of psychiatric and neurological disorders. The putative psychoactive ingredient of Cannabis sativa (marijuana plant), $\Delta^{9}$-tetrahydrocannabinol $\left(\Delta^{9}\right.$-THC), as well as the endogenous cannabinoids anandamide (arachidonoyl ethanolamide) and

Abbreviations: 2-AG, 2- arachidonoylglycerol; $\mathrm{ACEA}$, arachidonyl-2-chloroethylamide; $\mathrm{CB}_{1}{ }^{-/-}, \mathrm{CB}_{1}$ knock-out mice; $\mathrm{CB}_{2}{ }^{-/}, \mathrm{CB}_{2}$ knock-out mice; $\mathrm{CB}_{1}{ }^{-/} / \mathrm{CB}_{2}{ }^{-/}, \mathrm{CB}_{1}$ and $\mathrm{CB}_{2}$ double knock-out mice; $\mathrm{P} 1$, pellet fraction; $\mathrm{P} 2$, membrane enriched fraction; PVT, polyvinyltoluene; RT, room temperature; SDS, sodium dodecyl sulfate; SPA, scintillation proximity assay; TBS, tris-buffered saline; WT, wild type; $\Delta^{9}$-THC, $\Delta^{9}$-tetrahydrocannabinol. 
2-arachidonoylglycerol (2-AG) act primarily through cannabinoid $\mathrm{CB}_{1}$ and $\mathrm{CB}_{2}$ receptors. These cannabinoid receptors are GPCRs mostly coupled to Gi/o proteins (Howlett et al., 2002). The $\mathrm{CB}_{1}$ receptor is mainly distributed in the CNS, particularly in cortex, basal ganglia, hippocampus, and cerebellum (Mackie, 2005; De Jesus et al., 2006) and generally acts presinaptically inhibiting the release of neurotransmitters. $\mathrm{CB}_{2}$ receptors are expressed at much lower levels in the CNS compared with $\mathrm{CB}_{1}$ receptors (reviewed in Atwood and Mackie, 2010). As $\mathrm{G}_{\mathrm{i} / \mathrm{o}}$ coupled GPCRs, $\mathrm{CB}_{1}$ and $\mathrm{CB}_{2}$ receptors inhibit adenylyl cyclase, but moreover, both receptors are able to activate MAPK, inhibit voltage gated $\mathrm{Ca}^{2+}$ channels and activate inwardly rectifying $\mathrm{K}^{+}$channels (Childers et al., 1993).

The activation of $\mathrm{CB}_{1}$ receptor in the brain leads to the modulation of neuronal excitability, which may be in part responsible of the psychoactive effects of exogenous cannabinoids. In this context, a considerable amount of studies have been performed in order to elucidate the effects of cannabinoids (natural or synthetics) in the development of mental alterations, such as addiction, cognitive deficits, anxiety or psychosis. Importantly, different or opposite behavioral effects have been observed after the administration of $\Delta^{9}$-THC or synthetic cannabinoid ligands (Fattore et al., 2003; Panagis et al., 2014; Rubino and Parolaro, 2016). It has been demonstrated that for most $\mathrm{G}$ protein-coupled receptors, distinct agonists can differentially regulate several signaling pathways through the same receptor by a selective activation of different intracellular effectors. This is a mechanism known as functional selectivity or biased agonism. In this way, cannabinoid receptors have been demonstrated to be capable of coupling to different families of $\mathrm{G}$ proteins and/or to beta-arrestin when activated by an agonist drug suggesting that different intracellular responses may be activated depending on the ligand (Glass and Northup, 1999; Bosier et al., 2010). For instance, for the $\mathrm{CB}_{1}$ receptor has been reported that, whereas 2-AG and WIN55,212 have little preference for inhibition of cAMP and phosphorylation of ERK1/2, anandamide and CP55940 were biased toward cAMP inhibition (Khajehali et al., 2015). Moreover, in a recent study Dhopeshwarkar and Mackie (2016) demonstrated that $\mathrm{CB}_{2}$ receptor ligands display strong and varied functional selectivity at canonical (inhibition of adenylyl cyclase) and non-canonical (arrestin recruitment) pathways. Moreover, the intracellular signaling activated by a receptor depends on the cellular system where it is expressed, which may vary across different neuronal environments. In this context, it has been demonstrated that opioid and cannabinoid receptors function through the same pool of $G$ proteins when they are co-transfected, whereas in cells endogenously expressing these receptors signaling occurs through distinct pools of $G$ proteins (Shapira et al., 2000). Thus, this fact should be taken into consideration when interpreting results acquired in artificially transfected cells vs. native biological systems.

To our knowledge, no study has compared G protein signaling by different cannabinoid drugs in native brain tissue. Thus, in the current study, we performed $\left[{ }^{35} \mathrm{~S}\right] \mathrm{GTP} \gamma \mathrm{S}$ scintillation proximity assay (SPAs) coupled with the use of specific antibodies against different $G \alpha$ protein subunits to evaluate the functional selectivity of different cannabinoid ligands by activating $\mathrm{CB}_{1}$ and/or $\mathrm{CB}_{2}$ cannabinoid receptors in mouse brain cortex.

\section{MATERIALS AND METHODS}

\section{Animal Procedures}

Adult C57BL/6J (WT), $\mathrm{CB}_{1}$ knock-out $\left(\mathrm{CB}_{1}^{-/-}\right.$) (Marsicano et al., 2002), $\mathrm{CB}_{2}$ knock-out $\left(\mathrm{CB}_{2}^{-/-}\right)$(Buckley et al., 2000), and $\mathrm{CB}_{1} / \mathrm{CB}_{2}$ double knock-out $\left(\mathrm{CB}_{1}^{-/-} / \mathrm{CB}_{2}{ }^{-/-}\right)$mice were used in this study. Animals (males, aged 7-8 weeks-old) were housed (6-8 animals per cage) in standard cages under controlled conditions of temperature $\left(23 \pm 1^{\circ} \mathrm{C}\right)$ and photoperiod (light/dark cycle $14 \mathrm{~h}: 10 \mathrm{~h}$ ) and free access to standard rodent chow and water.

\section{Animal Welfare and Ethical Statements}

All experimental procedures using mice were performed in accordance with the European Directive for the Protection of Vertebrate Animals used for experimental and Other Scientific Purposes (European Union Directive \#86/606/EEC) and approved by the Ethics Committees for Animal Welfare of the University of the Basque Country (UPV/EHU) permit number CEBA1882011 and by the Institutional Review Board (INIA), permit number CEEA2012/021.

\section{Rationale for Choice of Cannabinoid Ligands}

In the present study, we decided to investigate the effects of three different cannabinoid ligands. $\Delta^{9}$-THC was chosen for being the main psychoactive component of marijuana plant and the putative responsible of the development of mental disorders in humans. WIN55212-2, a synthetic cannabinoid structurally different from $\Delta^{9}-\mathrm{THC}$, is a potent, non-selective $\mathrm{CB}_{1} / \mathrm{CB}_{2}$ receptor agonist that is frequently used in the studies that try to elucidate the effects of Cannabis in the brain. Finally, we wanted to study a ligand structurally similar to endogenous cannabinoids, such as the synthetic anandamide analog arachidonyl-2-chloroethylamide (ACEA). O-2050 was chosen as a neutral cannabinoid antagonist. O-2050 has been proved to be a neutral $\mathrm{CB}_{1}$ receptor antagonist in several studies (Canals and Milligan, 2008; Hudson et al., 2010; Brents et al., 2011; Wiley et al., 2011), with quite similar affinity for $\mathrm{CB}_{1}$ and $\mathrm{CB}_{2}$ receptors. Although, there is some data in the literature suggesting its activity as inverse or even partial agonist at $\mathrm{CB}_{1}$ receptors in various tissues (Makwana et al., 2010; Wiley et al., 2011) in a previous work of our group, we showed that $\mathrm{O}-2050$ has no effect over $\left[{ }^{35} \mathrm{~S}\right] \mathrm{GTP} \gamma \mathrm{S}$ binding and behaves as an antagonist blocking WIN55212-2-mediated activation (Erdozain et al., 2012) (Figure 1).

\section{Rationale for Choice of G Protein $\alpha$ Subunit Subtypes}

In the present study, we decided to investigate the ability of cannabinoid receptors to activate different $G$ proteins subtype. We chose at least one $G$ protein subtype representative of each 
$\Delta^{9}$-THC

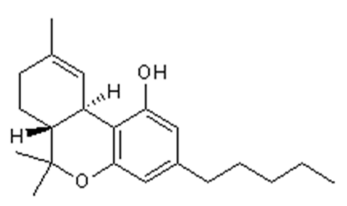

WIN55,212-2<smiles>Cc1c(C(=O)c2cccc3ccccc23)c2cccc3c2n1[C@H](CN1CCOCC1)CO3</smiles>

O-2050
ACEA<smiles>CCCCC/C=C\C/C=C\C/C=C\CCCC(=O)NCCCl</smiles><smiles>CC1=CC[C@H]2[C@@H](C1)c1c(O)cc(CC#CCCCNS(C)(=O)=O)cc1OC2(C)C</smiles>

FIGURE 1 | Chemical structure of the different cannabinoid ligands used. Representative scheme of the chemical structure of the different cannabinoid ligands used in this study ( $\Delta^{9}$-tetrahydrocannabinol ( $\Delta^{9}$-THC), WIN55212-2, arachidonyl-2-chloroethylamide (ACEA) and O-2050).

main $G$ protein family and mainly focusing in the inhibitory $G$ proteins for being the cannabinoid canonical pathway (Figure 2).

\section{Mouse Brain Cortex Membrane Homogenates Preparation}

After sacrifice by cervical dislocation, the brains were rapidly removed, cortices dissected and fresh frozen, and stored immediately at $-80^{\circ} \mathrm{C}$ until use. Preparation of membrane enriched fraction (P2 fraction) was performed as previously described (Gonzalez-Maeso et al., 2000) with minor modifications. Mouse brain cortex samples (approximately $200 \mathrm{mg}$ ) from seven mice each time were thawed at $4^{\circ} \mathrm{C}$ and homogenized with a glass/teflon grinder (IKA labortechnik, Satufen, Germany) (10 strokes at maximum speed) in 30 volumes of homogenization buffer ( $50 \mathrm{mM}$ Tris- $\mathrm{HCl}$ (Invitrogen, Barcelona, Spain), 1 mM EGTA (Sigma-Aldrich, St. Louis, MO, USA), $3 \mathrm{mM} \mathrm{MgCl} 2$ (Sigma-Aldrich, St. Louis, MO, USA) and 1 mM DTT (Invitrogen, Barcelona, Spain); pH 7.4; supplemented with $250 \mathrm{mM}$ sucrose (Panreac Química S.A.U, Barcelona, Spain). The homogenates were centrifuged at $1,100 \times g$ for $10 \mathrm{~min}$ at $4^{\circ} \mathrm{C}$ (Sorvall RC-5C centrifuge, SM-24 rotor; FisherScientific, Madrid, Spain). The pellets (P1 fraction) were discarded and the supernatants were then recentrifuged at $40,000 \times g$ for $10 \mathrm{~min}$ $\left(4^{\circ} \mathrm{C}\right)$. The resultant pellets were resuspended in 20 volumes of fresh cold centrifugation buffer ( $50 \mathrm{mM}$ Tris-HCl, $1 \mathrm{mM}$ EGTA, $3 \mathrm{mM} \mathrm{MgCl}_{2}$ and $1 \mathrm{mM} \mathrm{DTT}$; pH 7.4) with a glass stick and recentrifuged at $40,000 \times \mathrm{g}$ for $10 \mathrm{~min}\left(4^{\circ} \mathrm{C}\right)$. The obtained pellets were then resuspended in five volumes of centrifugation buffer. Protein content was determined by the method of Bradford with BSA (Sigma-Aldrich ${ }^{\circledR}$, St. Louis, MO, USA) as standard. Linear regression analysis and extrapolation of the data were carried out with GraphPad Prism $5^{\circledR}$ software (GraphPad Software, Inc., San Diego, CA, USA). Finally, aliquots of 0.5, 1, and $2 \mathrm{mg}$ were then centrifuged at $21,000 \times g$ (Eppendorf $5810 \mathrm{R}$ centrifuge; Eppendorf, Madrid, Spain) during $15 \mathrm{~min}$ at $4^{\circ} \mathrm{C}$. The supernatant layer was carefully discarded and the pellets stored at $-80^{\circ} \mathrm{C}$ until assay.

\section{Antibody-Capture $\left[{ }^{35} \mathrm{~S}\right] \mathrm{GTP} \gamma \mathrm{S}$ Scintillation Proximity Assay (SPA)}

Specific activation of different subtypes of $\mathrm{G} \alpha$ proteins was determined using a homogeneous protocol of $\left[{ }^{35} \mathrm{~S}\right] \mathrm{GTP} \gamma \mathrm{S}$ SPA coupled with the use of specific antibodies essentially as previously described (Erdozain et al., 2012). $\left[{ }^{35}\right.$ S]GTP $\gamma S$ binding was performed in 96-well Isoplates (PerkinElmer Life Sciences, Maanstraat, Germany) and in a final volume of $200 \mathrm{ml}$ containing $1 \mathrm{mM}$ EGTA, $3 \mathrm{mM} \mathrm{MgCl} 2,100 \mathrm{mM} \mathrm{NaCl}, 0.2 \mathrm{mM}$ DTT, $50 \mathrm{mM}$ Tris- $\mathrm{HCl}$ at $\mathrm{pH} 7.4,0.4 \mathrm{nM}\left[{ }^{35} \mathrm{~S}\right] \mathrm{GTP} \gamma \mathrm{S}, 15 \mu \mathrm{g}$ of protein per well, and different concentrations of GDP depending on the $\mathrm{G} \alpha$ subunit subtype tested. At the end of the $2 \mathrm{~h}$ incubation period $\left(30^{\circ} \mathrm{C}\right), 20 \mu \mathrm{l}$ of Igepal $1 \%+$ SDS $0.1 \%$ were added to each well, and plates were incubated at $22^{\circ} \mathrm{C}$ for 30 min with gentle agitation. Specific antibody for the $G \alpha$ subunit of interest was then added to each well before an additional 90 min RT incubation period (the antibodies and dilutions employed are described in Table 1). Polyvinyltoluene (PVT) SPA beads coated with protein A (PerkinElmer, S.L., Tres Cantos, Madrid, Spain) were then added $(0.75 \mathrm{mg}$ of beads per well), and plates were incubated for $3 \mathrm{~h}$ at RT with gentle agitation. Finally, plates were centrifuged $(5 \mathrm{~min}$ at $1000 \times \mathrm{g}$ ), and bound radioactivity was detected on a MicroBeta TriLux scintillation counter (PerkinElmer S.L., Tres Cantos, Madrid, Spain). In order to test their effect on the $\left[{ }^{35} S\right] G T P \gamma S$ binding to the different $\mathrm{G} \alpha$ subunit subtypes, a single submaximal concentration of the drugs $(10 \mu \mathrm{M}) \Delta^{9}$-THC, WIN55212-2, ACEA and/or O-2050, was used. This submaximal concentration was chosen as previously reported (Erdozain et al., 2012) in our previous experimental assays in which we established the 


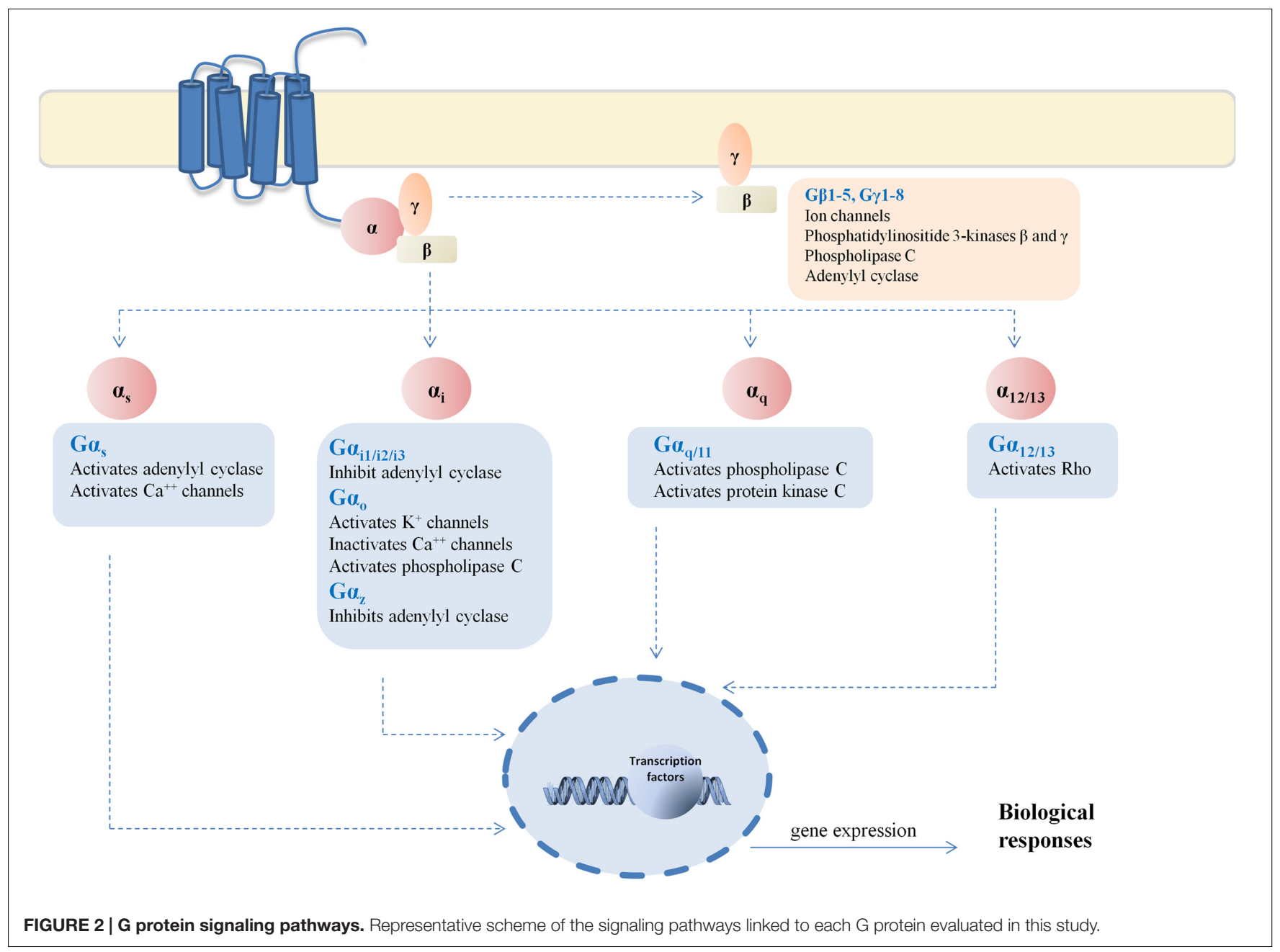

TABLE 1 | Antibodies, dilutions, and GDP concentrations employed in the $\left[{ }^{35} \mathrm{~S}\right] \mathrm{GTP} \gamma \mathrm{S}$ scintillation proximity assays.

\begin{tabular}{|c|c|c|c|c|c|}
\hline Target & Description & Commercial firm & Catalog \# & [GDP] $(\mu \mathrm{M})$ & Ab dilution \\
\hline $\mathrm{G} \alpha_{i 1}$ & Mouse monoclonal anti-G $\alpha_{i 1}$ & Santa Cruz & sc-56536 & 100 & $1: 20$ \\
\hline $\mathrm{G} \alpha_{\mathrm{i} 2}$ & Rabbit polyclonal anti-G $\alpha_{\mathrm{i} 2}$ & Santa Cruz & sc-7276 & 50 & $1: 20$ \\
\hline $\mathrm{G} \alpha_{\mathrm{i} 3}$ & Rabbit polyclonal anti-G $\alpha_{i 3}$ & Santa Cruz & sc-262 & 200 & $1: 30$ \\
\hline $\mathrm{G} \alpha_{\circ}$ & Mouse monoclonal anti-G $\alpha_{\circ}$ & BIOMOL & SA-280 & 50 & $1: 75$ \\
\hline $\mathrm{G} \alpha_{\mathrm{z}}$ & Rabbit polyclonal anti-G $\alpha_{z}$ & Santa Cruz & sc-388 & 100 & $1: 20$ \\
\hline $\mathrm{G} \alpha_{\mathrm{S}}$ & Rabbit polyclonal anti-G $\alpha_{S}$ & Santa Cruz & sc-383 & 100 & $1: 20$ \\
\hline $\mathrm{G} \alpha_{\mathrm{q} / 11}$ & Rabbit polyclonal anti-G $\alpha_{\mathrm{q} / 11}$ & Santa Cruz & sc-392 & 50 & $1: 20$ \\
\hline $\mathrm{G} \alpha_{12 / 13}$ & Rabbit polyclonal anti-G $\alpha_{12 / 13}$ & Santa Cruz & sc-28588 & 100 & $1: 20$ \\
\hline
\end{tabular}

standard conditions for this assays. This concentration is the one which give us binding values around the Emax for any drug and subunit subtype combination studied (Supplementary Figure S1). Non-specific binding was defined as the remaining $\left.{ }^{35} \mathrm{~S}\right] \mathrm{GTP} \gamma \mathrm{S}$ binding in the presence of $10 \mu \mathrm{M}$ unlabelled GTP $\gamma$ S.

\section{Western Blot}

For Western blot experiments, membrane enriched fraction (P2 fraction) pellets from mouse brain tissue (cortex) were resuspended in TBS, reaching a concentration of $4 \mathrm{mg}$ protein/ml. Commercial Laemmli $2 \mathrm{x}(95 \%)$ and $\beta$ mercaptoethanol (5\%) (Sigma-Aldrich ${ }^{\circledast}$, St. Louis, MO, USA) were added to each sample, reaching a final protein concentration of $2 \mathrm{mg} / \mathrm{ml}$. Finally, all the samples were heated at $95^{\circ} \mathrm{C}$ for $5 \mathrm{~min}$ in a Thermoblock (Biometra, Goettingen, Germany) and kept at $-20^{\circ} \mathrm{C}$ until assay. Electrophoresis was carried out in SDS polyacrylamide gels, composed of $5 \%$ stacking $(0.5 \mathrm{M}$ Tris- $\mathrm{HCl}, \mathrm{pH} 6.8,10 \% \mathrm{SDS})$ and $12 \%$ resolving $(1.5 \mathrm{M}$ Tris- $\mathrm{HCl}, \mathrm{pH} 8.8,10 \%$ SDS $)$ gels, 
using a miniprotean system (Bio-Rad Laboratories). Equal protein loading in the gel was verified by simultaneous immunodetection of $\beta$-actin (mouse monoclonal antibody anti- $\beta$-actin, Sigma Biosciences, St. Louis, MO, USA) with the different $\mathrm{G} \alpha$ subunit subtypes. Proteins were then transferred to nitrocellulose membranes ( $1 \mathrm{~h}, 0.3 \mathrm{~A})$ using an electrophoretic transfer system (Bio-Rad Laboratories). The non-specific binding sites in the membranes were blocked for $1 \mathrm{~h}$ at $\mathrm{RT}$ in blocking solution ( $3 \%$ non-fat dry milk, $\mathrm{pH}=7.4$ in PBS). Membranes were incubated overnight at $4^{\circ} \mathrm{C}$ in incubation buffer (3\% non-fat dry milk $+0.1 \%$ Tween-20 in PBS) containing the appropriate dilution of the specific primary anti-G $\alpha$ subunit antibody. Antibody specificity, as previously described in the literature (Gettys et al., 1994; Valdizan et al., 2010), was confirmed in our experimental conditions by Western blot (data not shown). Membranes were washed with PBS and incubated for $1 \mathrm{~h}$ at RT and constant agitation with the fluorescent conjugated secondary antibodies (Alexa Fluor ${ }^{\circledR} 680$ and/or IRDye 800 conjugated antibodies) suitable diluted in incubation buffer. Finally, membranes were rewashed with PBS and immunoreactivity was detected and quantified using the Odyssey Infrared Imaging System (LI-COR Biosciences, Lincoln, NE, USA) and Odyssey Software. Broad-Range pre-stained SDS-PAGE molecular weight standard (Bio-Rad Laboratories, Hercules, CA, USA) was used.

\section{Data Analysis and Statistical Procedures}

Data were analyzed with GraphPad Prism ${ }^{\mathrm{TM}} 5.01$ software. In order to allow better interpretation of the data, specific binding obtained from $\left[{ }^{35} \mathrm{~S}\right] \mathrm{GTP} \gamma \mathrm{S}$ SPAs were transformed to percentage of basal binding (binding values observed in the absence of any exogenous drug) obtained for each $\mathrm{G} \alpha$ protein subunit studied. The statistical comparison of the SPA results was carried out by a two-tailed one sample Student's $t$-test with a significance level of $p<0.05$. Immunodensity data obtained from Western blotting assays were transformed to percentage of the control, being the control the mean of immunodensities obtained for WT mice. The statistical comparison of the Western blot results was carried out by a one-way ANOVA test, followed by Dunnet's post hoc test for multiple comparisons, with a significance level of $p<0.05$. All data are expressed as mean \pm SEM values.

\section{Materials}

$\left[{ }^{35} \mathrm{~S}\right] \mathrm{GTP} \gamma \mathrm{S}\left(4625 \times 10^{10} \mathrm{~Bq} / \mathrm{mmol}\right)$ was purchased from PerkinElmer Life Sciences (Maanstraat, Germany). Tetrahydrocannabinol ( $\Delta^{9}$-THC) was purchased from THCPharm $\mathrm{GmbH}$ (Frankfurt, Germany); WIN55212-2 and GTP $\gamma$ S were purchased from Sigma-Aldrich (St. Louis, MO, USA); Arachidonyl2-chloroethylamide ACEA and O-2050 were from Tocris Bioscience (Bristol, UK). All other chemical reagents were of analytical quality and were purchased from Merck (Darmstadt, Germany) or Sigma-Aldrich (St. Louis, MO, USA).

\section{RESULTS}

\section{Effects of $\Delta^{9}$-THC, WIN55212-2, and ACEA on G Protein Activation in Mouse Brain Membranes}

Cannabinoid receptor ligands were used for the characterization of the functional coupling of cannabinoid receptors to the different $G$ protein $\alpha$ subunit subtypes $\left(\mathrm{G} \alpha_{\mathrm{i} 1}, \mathrm{G} \alpha_{\mathrm{i} 2}, \mathrm{G} \alpha_{\mathrm{i} 3}, \mathrm{G} \alpha_{\mathrm{o}}\right.$, $\mathrm{G} \alpha_{\mathrm{z}}, \mathrm{G} \alpha_{\mathrm{s}}, \mathrm{G} \alpha_{\mathrm{q} / 11}$, and $\left.\mathrm{G} \alpha_{12 / 13}\right)$ in mouse brain tissue. First, we investigated which $G \alpha$ subunit subtypes were activated by the natural cannabinoid $\Delta^{9}$-THC $(10 \mu \mathrm{M})$ in mouse brain cortex membrane homogenates (Figure 3A). As expected, we found that $\Delta^{9}$-THC was able to significantly activate several classical AC inhibitory subunits, as $\mathrm{G}_{\mathrm{il}}(113 \pm 3 \%), \mathrm{G} \alpha_{\mathrm{o}}$ $(110 \pm 2 \%)$, and $\mathrm{G} \alpha_{z}(113 \pm 5 \%)$, while exerted no effect on $\mathrm{G} \alpha_{\mathrm{i} 2}$ or $\mathrm{G} \alpha_{\mathrm{i} 3} . \Delta^{9}$-THC was also able to activate the $\mathrm{G} \alpha_{\mathrm{q} / 11}$ subunit $(118 \pm 5 \%)$. However, no changes were observed when we studied AC stimulatory subunit $\mathrm{G} \alpha_{\mathrm{s}}$ and the RhoA activator $\mathrm{G} \alpha_{12 / 13}$ subunit. To further test if these effects of $\Delta^{9}$ THC were cannabinoid-receptor mediated, the same assays were carried out in the presence of a putative neutral antagonist of the $\mathrm{CB}_{1}$ receptor, $\mathrm{O}-2050$. In all cases, the activation of these $\mathrm{G}$ protein subunits was blocked when membranes were co-incubated with the cannabinoid antagonist O-2050. Next, we investigated the effects on $G$ protein subunit activation induced by the synthetic cannabinoid agonist WIN55212-2 (Figure 3B). We found that WIN55212-2 significantly increased the binding of $\left[{ }^{35} \mathrm{~S}\right] \mathrm{GTP} \gamma \mathrm{S}$ to the all the inhibitory subunits $\mathrm{G} \alpha_{\mathrm{i} 1} \quad(129 \pm 6 \%), \quad \mathrm{G} \alpha_{\mathrm{i} 3} \quad(129 \pm 5 \%), \quad \mathrm{G} \alpha_{\mathrm{o}}(120 \pm 4 \%)$ and $\mathrm{G} \alpha_{\mathrm{z}}(134 \pm 6 \%)$, except $\mathrm{G} \alpha_{\mathrm{i} 2}$. WIN55212-2 was also able to activate the $\mathrm{G} \alpha_{\mathrm{q} / 11}$ subunit $(131 \pm 7 \%$ ), but not the AC stimulatory subunit $G \alpha_{s}$. Surprisingly, WIN55212-2 was also able to significantly stimulate the RhoA activator $\mathrm{G} \alpha_{12 / 13}(130 \pm 4 \%)$. In the same way as previously described for $\Delta^{9}$-THC, the activation of these $G$ protein subunits by WIN55212-2 was always blocked by the co-incubation with the cannabinoid antagonist O-2050, except for the case of $G \alpha_{z}(106 \pm 1 \%)$. Finally, we investigated the effect of the synthetic anandamide analog ACEA on G protein subunit activation in mouse brain tissue (Figure 3C). When evaluating the classical AC inhibitory subunits, we found that ACEA stimulated $\mathrm{G} \alpha_{\mathrm{i} 1}(121 \pm 4 \%), \mathrm{G} \alpha_{\mathrm{i} 3}(120 \pm 5 \%)$, and $\mathrm{G} \alpha_{\mathrm{o}}$ $(116 \pm 4 \%)$. However, as occurred with $\Delta^{9}$-THC and WIN552122, no stimulation was observed in $\mathrm{G} \alpha_{\mathrm{i} 2}$, suggesting that none of the cannabinoids evaluated exert their effects through $\mathrm{G} \alpha_{\mathrm{i} 2}$ signaling. Moreover, ACEA had no effect on $\mathrm{G}_{\mathrm{z}}$. As previously observed for the other two cannabinoid ligands evaluated, ACEA also activated $\mathrm{G} \alpha_{\mathrm{q} / 11}$ subunit $(122 \pm 7 \%)$ while had no effect on $G \alpha_{s}$. Thus, it seems that none of these cannabinoid ligands are able to activate this AC stimulatory subunit either. No changes were observed when we studied the effects of ACEA on the RhoA activator $G \alpha_{12 / 13}$ subunit. Again, the activation of these $G$ protein subunits was blocked when membranes were co-incubated with the cannabinoid antagonist O-2050. 

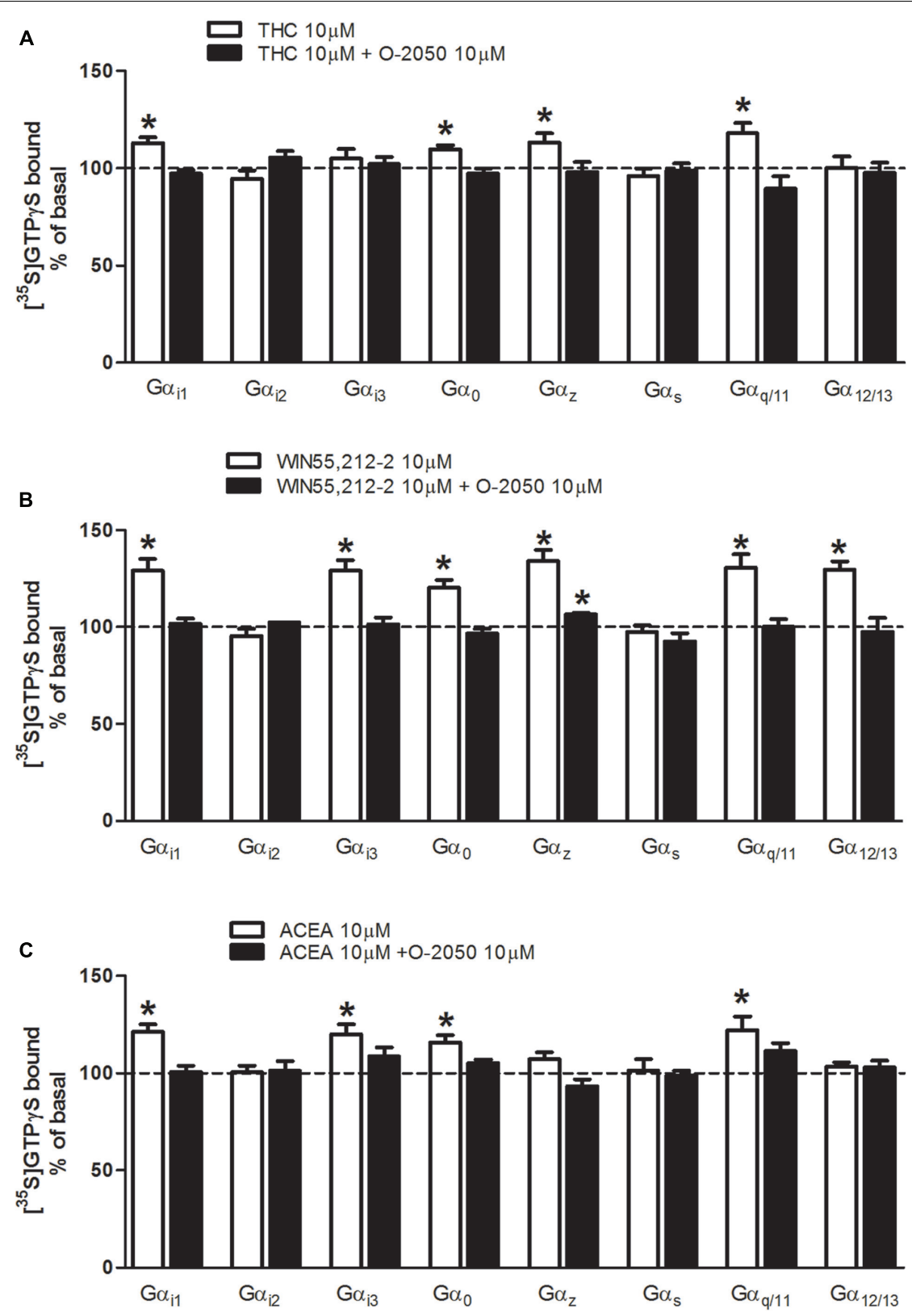

FIGURE 3 | Effects of THC, WIN55212-2, and ACEA on G protein activation in mouse brain membranes. [ ${ }^{35}$ S]GTP $\gamma$ S scintillation proximity assays coupled to immunoprecipitation with specific antibodies against different $\mathrm{G} \alpha$ subunits $\left(\mathrm{G} \alpha_{\mathrm{i} 1}, \mathrm{G} \alpha_{\mathrm{i} 2}, \mathrm{G} \alpha_{\mathrm{i} 3}, \mathrm{G} \alpha_{0}, \mathrm{G} \alpha_{\mathrm{z}}, \mathrm{G} \alpha_{\mathrm{S}}, \mathrm{G} \alpha_{\mathrm{q} / 11}\right.$, and $\left.\mathrm{G} \alpha_{12 / 13}\right)$ in mouse brain cortical membranes co-incubated with (A) THC (10 $\mu \mathrm{M})$ (B) WIN55212-2 (10 $\mu \mathrm{M})$, or (C) ACEA (10 $\mu \mathrm{M})$ in the presence or absence of the antagonist O-2050 (10 $\mu \mathrm{M})$. Data are shown as percentage of $\left[{ }^{35} \mathrm{~S}\right] \mathrm{GTP} \gamma \mathrm{S}$ basal binding values obtained for each specific subunit. Bars represent mean $\pm \mathrm{SEM}$ of four to six different experiments carried out in triplicate. Asterisks highlight those normalized values of stimulation or inhibition of basal binding which are statistically different from $100 \%$ (Student's t-test; * $p<0.05)$

\section{Effects of the Cannabinoid Antagonist 0-2050 on G Protein Activation in Mouse Brain Membrane Homogenates}

O-2050 was initially synthesized and described as a neutral $\mathrm{CB}_{1}$ receptor antagonist, however, there are some evidences suggesting that is able to act as an inverse agonist or even as a partial agonist (Wiley et al., 2011). For this reason, and in order to validate O-2050 as a useful pharmacological tool to antagonize the effect mediated by cannabinoid receptors, $\left[{ }^{35} S\right]$ GTP $\gamma S$ SPAs were performed in mouse cortical membranes in the presence of O-2050 (10 $\mu \mathrm{M})$ alone. Under these experimental conditions, neither stimulation nor inhibition of $\left[{ }^{35} \mathrm{~S}\right] \mathrm{GTP} \gamma \mathrm{S}$ basal binding values were observed for any of the $\mathrm{G} \alpha$ subunit subtypes studied, with the exception of $\mathrm{G} \alpha_{\mathrm{z}}(119 \pm 1 \%)$ (Figure 4). 


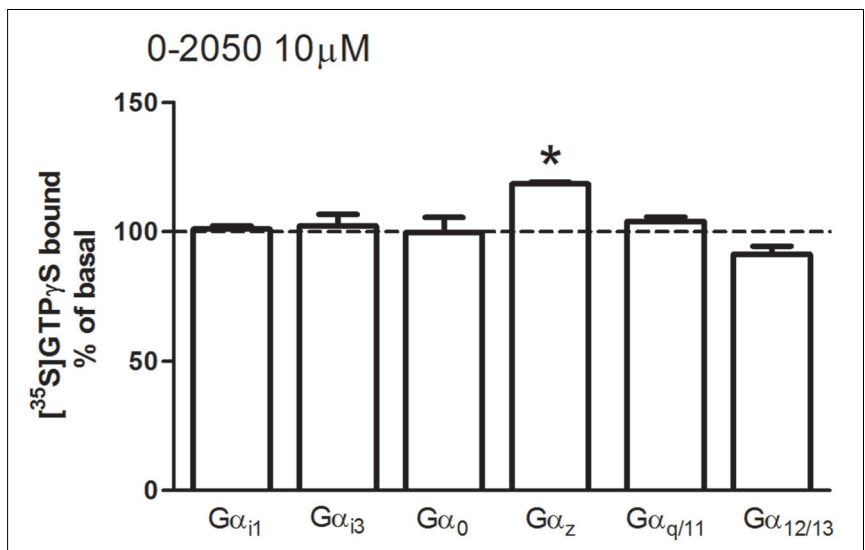

FIGURE 4 | Effects of the cannabinoid antagonist O-2050 on G protein activation in mouse brain membranes. $\left[{ }^{35} \mathrm{~S}\right] \mathrm{GTP} \gamma \mathrm{S}$ scintillation proximity assays coupled to immunoprecipitation with anti-G $\alpha_{i 1}, G \alpha_{i 3}, G \alpha_{0}, G \alpha_{z}$, $\mathrm{G} \alpha_{\mathrm{q} / 11}$, and $\mathrm{G} \alpha_{12 / 13}$ specific antibodies in mouse brain cortical membranes co-incubated with the cannabinoid antagonist O-2050 (10 $\mu \mathrm{M})$. Data are shown as percentage of $\left.{ }^{35} \mathrm{~S}\right] \mathrm{GTP} \gamma \mathrm{S}$ basal binding values obtained for each specific subunit. Bars represent mean \pm SEM of four to six different experiments carried out in triplicate. Asterisks highlight those normalized values of stimulation or inhibition of basal binding which are statistically different from $100 \%$ (Student's $t$-test; ${ }^{*} p<0.05$ ).

\section{Effects of $\Delta^{9}$-THC, WIN55212-2, and ACEA on G Protein Activation in Cannabinoid Receptors Knockout Mice}

To further elucidate the role of each cannabinoid receptor subtype in the agonist-mediated activation of the different $\mathrm{G} \alpha$ subunit subtypes, $\left[{ }^{35} \mathrm{~S}\right] \mathrm{GTP} \gamma \mathrm{S}$ SPA was performed in brain tissue of $\mathrm{CB}_{1}^{-/-}, \mathrm{CB}_{2}^{-/-}$, and $\mathrm{CB}_{1}^{-/-} / \mathrm{CB}_{2}^{-/-}$mice. For that purpose, brain membranes were incubated with the different cannabinoid ligands (THC, WIN55212-2, or ACEA) and with the specific antibodies against that $\mathrm{G} \alpha$ for which an stimulation with these agonists was observed in WT. Figure $5 \mathbf{A}$ shows the stimulation of the different $\mathrm{G} \alpha$ subunits when brain membranes of the four genotypes were incubated with $\Delta^{9}$-THC. The significant stimulation of the inhibitory $\mathrm{G} \alpha_{\mathrm{il}}$ subunit observed in the WT mice was completely absent in the $\mathrm{CB}_{1}^{-/-}$and in the $\mathrm{CB}_{1} / \mathrm{CB}_{2}$ double ko mice, but was still present in the $\mathrm{CB}_{2}^{-/-}(108 \pm 2 \%)$, which suggests that the $\Delta^{9}$-THC-mediated stimulation of $\mathrm{G}_{\mathrm{i} 1}$ is induced by the activation of $\mathrm{CB}_{1}$ receptor. On the other hand, opposite results were obtained for $\mathrm{G} \alpha_{i o}$ and $\mathrm{G} \alpha_{\mathrm{z}}$, the other two inhibitory subunits that were stimulated by $\Delta^{9}$ THC. As previously described, there was a significant $\Delta^{9}$-THCinduced stimulation of $\mathrm{G \alpha}_{\mathrm{o}}$ and $\mathrm{G}_{\mathrm{z}}$ subunits in the WT. This stimulation was also observed in the $\mathrm{CB}_{1}^{-/-}(115 \pm 4 \%$ for $\mathrm{G} \alpha_{\mathrm{o}}$ and $120 \pm 4 \%$ for $\mathrm{G} \alpha_{\mathrm{z}}$ ) but not in the $\mathrm{CB}_{2}{ }^{-/-}$ or the $\mathrm{CB}_{1}^{-/-} / \mathrm{CB}_{2}^{-/-}$mice. These data may indicate that, in mouse brain cortical membranes, $\Delta^{9}$-THC acts through the $\mathrm{CB}_{2}$ receptor to stimulate these inhibitory $\mathrm{G} \alpha_{\mathrm{o}}$ and $\mathrm{G} \alpha_{\mathrm{z}}$ subunits. Finally, the $\Delta^{9}$-THC-induced activation of the $\mathrm{G} \alpha_{\mathrm{q} / 11}$ subunit observed in the WT mice was not found in the $\mathrm{CB}_{1}{ }^{-/-}$and $\mathrm{CB}_{1}^{-/-} / \mathrm{CB}_{2}^{-/-}$mice, while remained unchanged in the $\mathrm{CB}_{2}{ }^{-/-}(116 \pm 2 \%)$. This result indicates that $\Delta^{9}-\mathrm{THC}$ stimulates the $G \alpha_{q / 11}$ subunit acting mainly through the $\mathrm{CB}_{1}$ receptor.

Figure 5B shows the stimulation of different $\mathrm{G} \alpha$ subunits when brain membranes of the four genotypes were incubated with the synthetic cannabinoid agonist WIN55212-2. The significant stimulation of the inhibitory $\mathrm{G} \alpha_{\mathrm{i} 1}$ and $\mathrm{G} \alpha_{\mathrm{i} 3}$ subunits induced by WIN55212-2 in the WT mice was not found in the $\mathrm{CB}_{1}^{-/-}$nor in the $\mathrm{CB}_{1}^{-/-} / \mathrm{CB}_{2}^{-/-}$mice, but was still present in the $\mathrm{CB}_{2}{ }^{-/-}\left(124 \pm 5 \%\right.$ for $\mathrm{G} \alpha_{\mathrm{i} 1}$ and $123 \pm 5 \%$ for $\left.\mathrm{G} \alpha_{i 3}\right)$. On the contrary, the inhibitory subunits $\mathrm{G} \alpha_{0}$ and $\mathrm{G} \alpha_{\mathrm{z}}$, which were significantly stimulated in the WT mice, remained stimulated in the $\mathrm{CB}_{1}{ }^{-/-}\left(111 \pm 2 \%\right.$ for $\mathrm{G} \alpha_{\mathrm{o}}$ and $123 \pm 7 \%$ for $\mathrm{G} \alpha_{\mathrm{z}}$ ) but not stimulation was found in the $\mathrm{CB}_{2}{ }^{-/-}$nor in the $\mathrm{CB}_{1}{ }^{-/-} / \mathrm{CB}_{2}{ }^{-/-}$mice. These results suggest that the inhibitory signaling of WIN55212-2 in the mice brain through $\mathrm{G}_{\mathrm{i} 1}$ and $\mathrm{G}_{\mathrm{i} 3}$ activation seems to be mediated by the $\mathrm{CB}_{1}$ receptor, while the stimulation of $\mathrm{G} \alpha_{0}$ and $\mathrm{G} \alpha_{z}$ would be mediated by the $\mathrm{CB}_{2}$ receptor activation. The significant activation of the $\mathrm{G} \alpha_{\mathrm{q} / 11}$ subunit induced by WIN55212-2 in the WT mice was completely absent in the $\mathrm{CB}_{1}{ }^{-/-}$mice, as well as in the $\mathrm{CB}_{1} / \mathrm{CB}_{2}$ double ko mice. On the contrary, a significant stimulation of $\mathrm{G} \alpha_{\mathrm{q} / 11}$ subunit $(120 \pm 5 \%)$ was observed in the $\mathrm{CB}_{2}{ }^{-/-}$ membranes, suggesting that this stimulation is mediated by the $\mathrm{CB}_{1}$ receptor. Strikingly, the observed stimulation of the RhoA activator subunit $\mathrm{G} \alpha_{12 / 13}$ by WIN55212-2 in the WT disappeared in the absence of $\mathrm{CB}_{2}$ receptor (both in $\mathrm{CB}_{2}{ }^{-/-}$ and $\mathrm{CB}_{1}{ }^{-/-} / \mathrm{CB}_{2}{ }^{-/-}$mice) suggesting an important role of this $\mathrm{CB}_{2}$ receptor in the intracellular signaling through $\mathrm{G} \alpha_{12 / 13}$ in the brain.

Finally, the same experiments were performed incubating the brain membranes with the synthetic anandamide analog ACEA (Figure 5C). Surprisingly, the significant stimulation of $\mathrm{G} \alpha_{\mathrm{i} 1}$ that was observed in the WT mice was still found in all the genotypes evaluated. These results suggest that the inhibitory effect of ACEA mediated by the $\mathrm{G} \alpha_{\mathrm{i} 1}$ subunit activation may be independent of cannabinoid receptors. On the other hand, the significant stimulation of $\mathrm{G} \alpha_{\mathrm{i} 3}$ subunit induced by ACEA was not observed in brain membranes of $\mathrm{CB}_{1}^{-/-}$ mice but was still significant in $\mathrm{CB}_{2}{ }^{-/-}$membranes $(111 \pm 3 \%)$. No stimulation was observed in the $\mathrm{CB}_{1}{ }^{-/-} / \mathrm{CB}_{2}{ }^{-/-}$mice. Regarding the $\mathrm{G} \alpha_{0}$ subunit, there was a significant stimulation in the absence of $\mathrm{CB}_{1}$ receptors $(115 \pm 1 \%)$, while this stimulation was not observed in the brain membranes of $\mathrm{CB}_{2}{ }^{-/-}$mice, suggesting the necessary role of this receptor in the activation of $\mathrm{G} \alpha_{0}$ induced by the agonist ACEA. The activation of the $\mathrm{G} \alpha_{\mathrm{q} / 11}$ subunit was observed in both $\mathrm{CB}_{1}{ }^{-/-}(117 \pm 2 \%)$ and $\mathrm{CB}_{2}^{-/-}(118 \pm 4 \%)$ but not in the $\mathrm{CB}_{1}{ }^{-/-} / \mathrm{CB}_{2}{ }^{-/-}$mice. Thus, as for $\Delta^{9}-\mathrm{THC}$ and WIN552122, the activation of $\mathrm{G}_{\mathrm{i} 3}$ and $\mathrm{G} \alpha_{\mathrm{o}}$ subunits was mediated by their interaction with $\mathrm{CB}_{1}$ and $\mathrm{CB}_{2}$ receptors, respectively. However, the stimulation of $\left[{ }^{35} \mathrm{~S}\right] \mathrm{GTP} \gamma \mathrm{S}$ binding to $\mathrm{G} \alpha_{\mathrm{q} / 11}$ subunit seems to be triggered by the activation of both $\mathrm{CB}_{1}$ and $\mathrm{CB}_{2}$ cannabinoid receptors. 


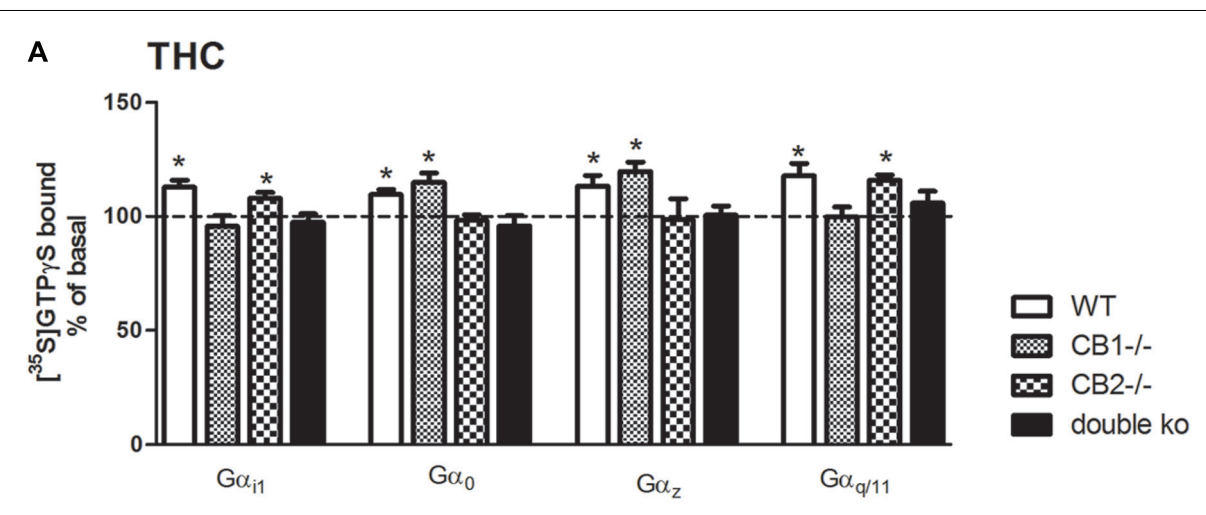

B
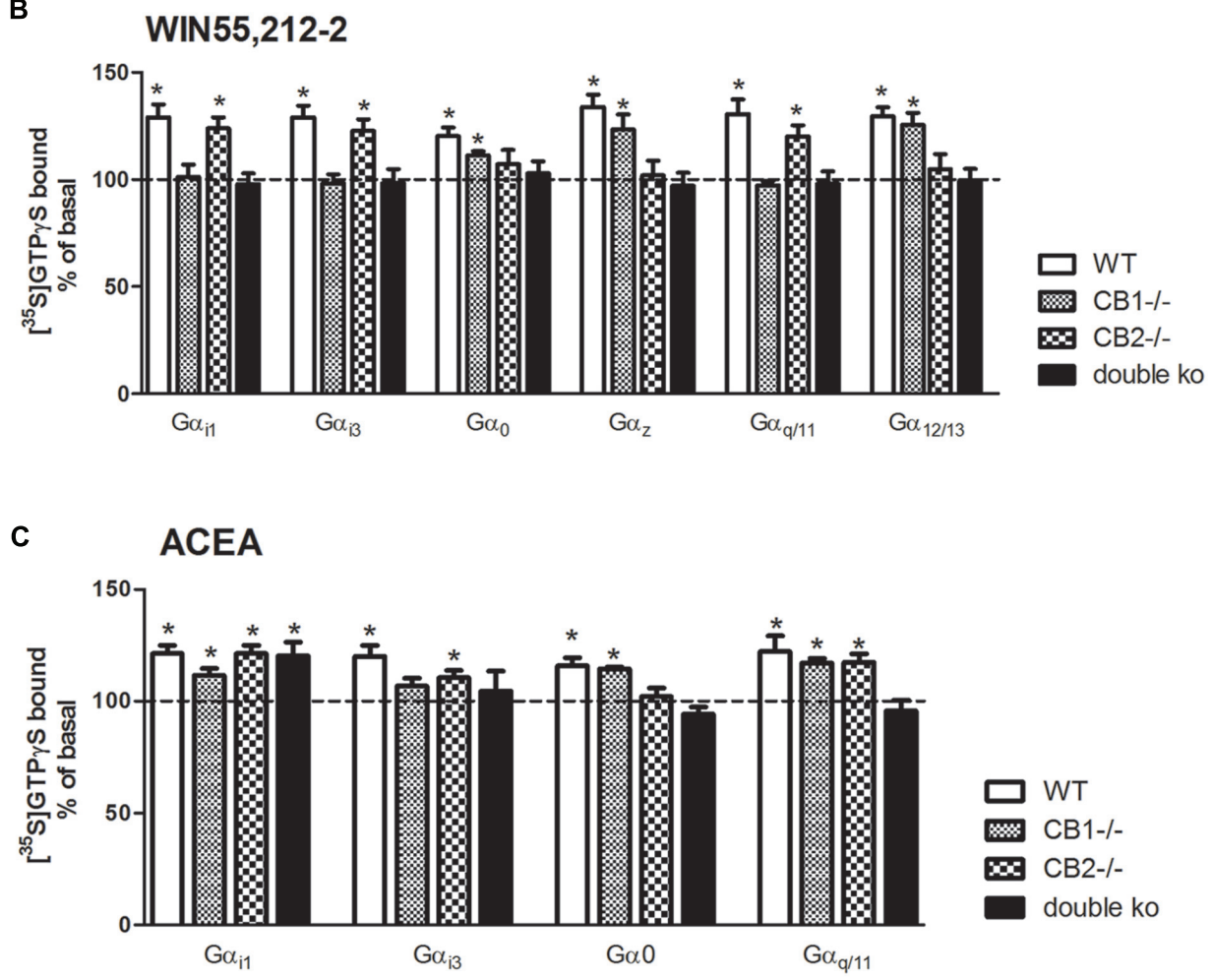

FIGURE 5 | Effects of THC, WIN55, 212-2, and ACEA on G protein activation in cannabinoid receptors knockout mice. [ ${ }^{35}$ S]GTP $\gamma$ S scintillation proximity

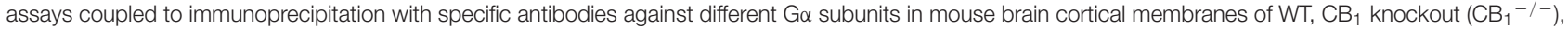
$\mathrm{CB}_{2}$ knockout $\left(\mathrm{CB}_{2}^{-/-}\right)$and double $\mathrm{CB}_{1}$ and $\mathrm{CB}_{2}$ knockout $\left(\mathrm{CB}_{1}^{-/-} / \mathrm{CB}_{2}^{-/-}\right.$/double $\left.\mathrm{KO}\right)$ co-incubated with (A) THC (10 $\left.\mu \mathrm{M}\right)$ (B) WIN55212-2 (10 $\left.\mu \mathrm{M}\right)$, or (C) ACEA $(10 \mu \mathrm{M})$. Data are shown as percentage of $\left[{ }^{35} \mathrm{~S}\right] \mathrm{GTP} \gamma \mathrm{S}$ basal binding values obtained for each specific subunit. Bars represent mean \pm SEM of four to six different experiments carried out in triplicate. Asterisks highlight those normalized values of stimulation or inhibition of basal binding which are statistically different from $100 \%$ (Student's $t$-test; * $p<0.05)$.

\section{Expression of G Protein Subunits in Knockout Mice for Cannabinoid Receptors}

In order to determine if a physiological adaptation of knockout mice to the genetic manipulation to inactivate $\mathrm{CB}_{1}$ and/or $\mathrm{CB}_{2}$ receptors may influence our results by the alteration of the expression level of the different $\mathrm{G} \alpha$ protein subunits, Western blotting assays were carried out in brain cortex membranes of $\mathrm{WT}, \mathrm{CB}_{1}^{-/-}, \mathrm{CB}_{2}^{-/-}$, and $\mathrm{CB}_{1}^{-/-} / \mathrm{CB}_{2}^{-/-}$mice.
In the case of $\mathrm{G}_{\mathrm{i} 1}$ (Figure 6A), no changes were observed for $\mathrm{CB}_{1}{ }^{-/-}$and $\mathrm{CB}_{2}{ }^{-/-}$, but a significant reduction $(33 \pm 10 \%$ from WT) of immunodensity was detected in $\mathrm{CB}_{1}{ }^{-/-} / \mathrm{CB}_{2}{ }^{-/-}$ mice brain membrane homogenates. No significant differences were found in the expression of $\mathrm{G}_{\mathrm{o}}$ (Figure 6C) or $\mathrm{G}_{12 / 13}$ (Figure 6F) subunits between the $\mathrm{WT}, \mathrm{CB}_{1}^{-/-}, \mathrm{CB}_{2}^{-/-}$, and $\mathrm{CB}_{1}{ }^{-/-} / \mathrm{CB}_{2}{ }^{-/-}$mice brain membranes. However, an increase in the expression of $\mathrm{G}_{\mathrm{i} 3}$ (Figure 6B) in both $\mathrm{CB}_{2}{ }^{-/-}(139 \pm 7 \%)$ and $\mathrm{CB}_{1}^{-/-} / \mathrm{CB}_{2}^{-/-}$mice $(140 \pm 7 \%)$ was found when compared to the WT and $\mathrm{CB}_{1}^{-/-}$animals. On the contrary, 


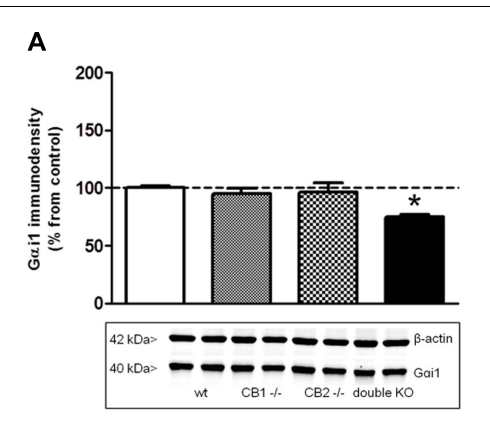

D

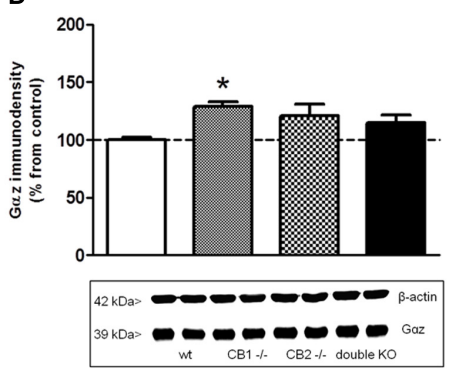

B

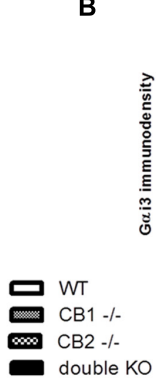

E

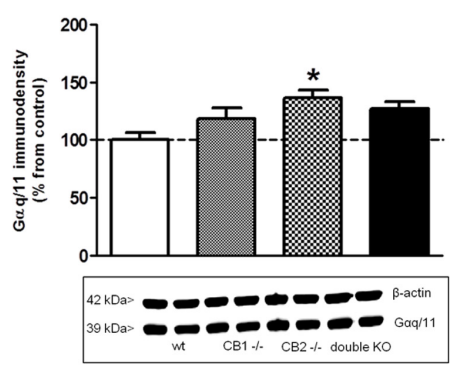

C

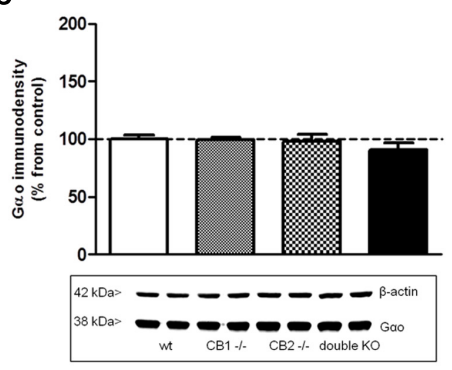

$\mathbf{F}$

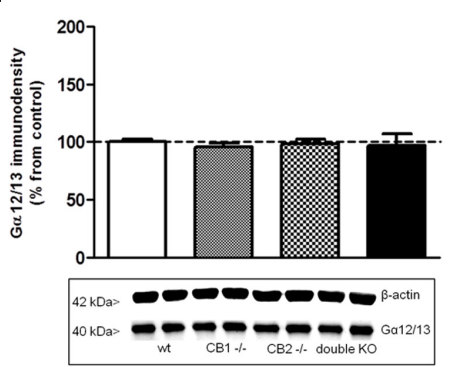

FIGURE 6 | Expression of G protein subunits in cannabinoid receptors knockout mice. Immunoreactive signal and representative images obtained by Western blotting with specific antibodies against different $\mathrm{G} \alpha$ subunits: (A) $\mathrm{G} \alpha_{\mathrm{i1}}$, (B) $\mathrm{G} \alpha_{\mathrm{i3}}$, (C) $\mathrm{G} \alpha_{0}$, (D) $\mathrm{G} \alpha_{\mathrm{z}}$, (E) $\mathrm{G} \alpha_{\mathrm{q} / 11}$, and (F) $\mathrm{G} \alpha_{12 / 13}$ in mouse brain cortical membranes of $\mathrm{WT}, \mathrm{CB}_{1}$ knockout $\left(\mathrm{CB}_{1}^{-/-}\right), \mathrm{CB}_{2}$ knockout $\left(\mathrm{CB}_{2}{ }^{-/-}\right)$and double $\mathrm{CB}_{1}$ and $\mathrm{CB}_{2}$ knockout $\left(\mathrm{CB}_{1}{ }^{-/-} / \mathrm{CB}_{2}{ }^{-/-} /\right.$double $\left.\mathrm{KO}\right)$. Immunoreactivity for $\beta$-actin was simultaneously detected on every gel and used as loading control. Normalized values (percentage over controls) of Ga subunits are shown as mean \pm SEM of two different experiments carried out in duplicate. Asterisks highlight those values which are statistically different from WT (One-way ANOVA followed by Dunnet's post hoc test; * $p<0.05)$.

$\mathrm{G} \alpha_{\mathrm{z}}$ immunodensity was significantly increased in the $\mathrm{CB}_{1}^{-/-}$ mice $(129 \pm 4 \%)$ while no changes were found in the rest of the genotypes when comparing to the WT (Figure 6D). Finally, the expression of $\mathrm{G} \alpha_{\mathrm{q} / 11}$ (Figure 6E) was significantly increased in brain membranes of $\mathrm{CB}_{2}{ }^{-/-}$mice $(137 \pm 7 \%)$ but not in $\mathrm{WT}$, $\mathrm{CB}_{1}{ }^{-/-}$and $\mathrm{CB}_{1}{ }^{-/-} / \mathrm{CB}_{2}{ }^{-/-}$mice.

\section{DISCUSSION}

During the last years, a considerable effort has been made to study the effects of cannabinoids in the brain trying to elucidate the mechanisms by which these compounds may facilitate mental disorders, such as addiction, cognitive deficits, anxiety or psychosis. In this context, these studies have been performed with different cannabinoid ligands (natural or synthetics), in cells or in native tissue and/or in different animal species (mouse, rat, human...).

There is wide evidence supporting the idea that for most of GPCRs, distinct drugs are able to regulate different signaling pathways by the selective activation of different intracellular effectors. The pharmacological relevance of this fact is that the biological responses not only depend on targeting a specific GPCR but also on the particular pathway that this receptor activates. Different studies have focused on the evaluation of the functional selectivity of cannabinoid receptors, but most of them have been performed in transfected cells expressing the $\mathrm{CB}_{1}$ receptor (Glass and Northup, 1999; Bosier et al., 2010).
Moreover, much of these studies explore the signaling pathways activated by different agonists by the evaluation of cAMP production or the phoshorylation of intracellular mediators such as ERK or AKT, with no data about the $\mathrm{G} \alpha$ subtype responsible of these downstream effects. These changes on cAMP concentration or ERK/AKT phosphorylation could be the consequence of the activation of different $\mathrm{G} \alpha$ subtypes, $\mathrm{G} \beta \gamma$ dimmers, etc. On the other hand, and interestingly, opposite behavioral effects have been observed after the administration of $\Delta^{9}$-THC or synthetic cannabinoid ligands (Fattore et al., 2003; Panagis et al., 2014; Rubino and Parolaro, 2016). For example, when evaluating the cannabinoid effects on brainstimulation reward, Fattore et al. (2003) showed that the potent non-selective $\mathrm{CB}_{1} / \mathrm{CB}_{2}$ receptor agonists WIN55,212-2 and $\mathrm{CP}$ 55,940 , but not $\Delta^{9}$-THC, effectively restored heroin-seeking behavior. In addition, it has been suggested that the signaling of $\mathrm{CB}_{1}$ receptors may differ between humans and rodents (Straiker et al., 2012).

All these frequently contradictory data highlight the relevance of studying, simultaneously, the effects of different cannabinoid ligands in the same tissue and under the same experimental conditions.

For that reason the goal of the present study was to compare the pattern of $\mathrm{G}$ protein subunit stimulation triggered by three structurally different cannabinoids, $\Delta^{9}$-THC, WIN55212-2 and ACEA in mouse brain cortex. To our knowledge, this is the first study evaluating the cannabinoid-induced stimulation of the different $\mathrm{G} \alpha$ subunits in mouse brain tissue. 
WIN55212-2, a synthetic cannabinoid structurally different from $\Delta^{9}$-THC, is a potent, non-selective $\mathrm{CB}_{1} / \mathrm{CB}_{2}$ receptor agonist that has been used in many studies of cannabinoid receptor function (Pertwee et al., 2010). The synthetic anandamide analog ACEA is a highly selective agonist for the $\mathrm{CB}_{1}$ receptor with a low affinity for $\mathrm{CB}_{2}$ receptors (Hillard et al., 1999).

This study demonstrates that each ligand displays functional selectivity acting as biased agonist for a subset of different $\mathrm{G}$ protein subunits. It represents the first characterization of the activation of individual $\mathrm{G} \alpha$ subunits by endogenous cannabinoid receptors in brain cortex. Firstly, we demonstrated that phytocannabinoid $\Delta^{9}$-THC differs from the synthetic agonists WIN55212-2 and ACEA in its ability to stimulate $\mathrm{G} \alpha_{\mathrm{i} / \mathrm{o}}$ protein subunits in brain cortex.

The $G \alpha_{i}$ subfamily members $G \alpha_{i 1}, G \alpha_{i 2}$, and $G \alpha_{i 3}$ were originally identified by their ability to inhibit AC activity (Plummer et al., 2012; Busnelli et al., 2013; Minetti et al., 2014). Our results show that $\Delta^{9}$-THC, WIN55212-2, and ACEA significantly stimulate $\mathrm{G} \alpha_{\mathrm{i} 1}$ subunit. Moreover, data from knockout mice suggest that this effect may be $\mathrm{CB}_{1}$-mediated in the case of $\Delta^{9}$-THC and WIN55 212-2. However, the $G \alpha_{i 1}$ stimulation is still significant in membranes of all genotypes incubated with ACEA, suggesting that this is a non- $\mathrm{CB}_{1}$ non$\mathrm{CB}_{2}$ dependant effect and supporting putative actions of ACEA over other receptors (Pertwee et al., 2010). G $\alpha_{\mathrm{i} 3}$ subunit was also stimulated in the presence of WIN55212-2 and ACEA, but not of $\Delta^{9}$-THC. This stimulation seems to be mediated by $\mathrm{CB}_{1}$ receptors as is blocked in the presence of O-2050 and absent in $\mathrm{CB}_{1}^{-/-}$or $\mathrm{CB}_{1}^{-/-} / \mathrm{CB}_{2}{ }^{-/-}$mice. In the case of $\mathrm{G} \alpha_{\mathrm{i} 2}$, it has been previously described that WIN55212-2 is able to activate this subunit in rat (Prather et al., 2000) and in human brain cortical membranes (Erdozain et al., 2012). However, none of the agonists in the present study stimulated the $\mathrm{G} \alpha \alpha_{\mathrm{i} 2}$ subunit. This discrepancy may be due to inter-specie and/or regional differences, suggesting that WIN55212-2 may signal through different $G$ protein pools in human and mouse brain cortex.

These three $G \alpha_{i}$ subunits form the $G \alpha_{i} / o$ subfamily with the neuronal $\alpha$-subunit $G \alpha_{0}$, which corresponds to the most abundant $\mathrm{G} \alpha$ protein in brain (Sternweis and Robishaw, 1984). In our experimental approach, and in accordance with other studies (Glass and Northup, 1999; Presley et al., 2016), $\Delta^{9}$-THC, WIN55212-2 and ACEA significantly stimulated $\mathrm{G} \alpha_{\mathrm{o}}$. Results obtained in knockout animals show that the stimulation of $\mathrm{G} \alpha_{\mathrm{o}}$ in mouse cortex is mediated, at least in part, by $\mathrm{CB}_{2}$ receptors, suggesting a necessary role of this receptor in the cannabinoidinduced activation of $\mathrm{G} \alpha_{0}$.

The $G \alpha_{z}$ subtype is the most divergent member of the inhibitory subfamily and is distributed primarily in neuronal and neuroendocrine cells (Hinton et al., 1990). While $\Delta^{9}$-THC and WIN55212-2, similarly, stimulated $\mathrm{G} \alpha_{z}$, no stimulation of this subunit was observed when membranes were incubated with ACEA, suggesting that ACEA may not signal through this subunit. Additionally, results obtained with knockout mice suggest that the stimulation of $\mathrm{G} \alpha_{\mathrm{z}}$ by $\Delta^{9}$-THC and WIN55212-2 may be induced by a $\mathrm{CB}_{2}$-mediated mechanism.
Unlike $G \alpha_{z}$, the $G \alpha_{s}$ family is ubiquitously expressed and couples receptors to $\mathrm{AC}$ in a stimulatory fashion (Milligan and Kostenis, 2006). Under the present assay conditions, nor $\Delta^{9}$-THC, WIN55212-2 or ACEA were able to activate this stimulatory subunit. Thus, there is no evidence of $\mathrm{G} \alpha_{s}$ coupling of cannabinoid receptors in the presence of any of these drugs in brain tissue. There are contradictory results about the ability of cannabinoid drugs to activate $\mathrm{G} \alpha_{s}$ proteins. In this way, there are data from both $\mathrm{CHO}$ cell lines (Rinaldi-Carmona et al., 1996; Bonhaus et al., 1998) and HEK cells (Presley et al., 2016) expressing $\mathrm{CB}_{1}$ receptor, showing the absence of effect as well as a modest but significant coupling of $\mathrm{CB}_{1}$ to $\mathrm{G} \alpha_{s}$ triggered by different cannabinoids. It has been proposed that ACEA may elevate cAMP through a non- $\mathrm{CB}_{1}$ mechanism, since there is an increase in cAMP in both cells transfected and non-transfected with $\mathrm{CB}_{1}$ and pretreated with pertussis toxin (Presley et al., 2016). It is important to point out that all these studies have been performed in cell lines. Moreover, they use the accumulation of cAMP in the presence of the $G \alpha_{i / o}$ inhibitor pertussis toxin as an indirect evaluation of potential coupling of $\mathrm{CB}_{1}$ receptors to $\mathrm{G} \alpha_{s}$. This increase in cAMP production can be mediated by a mechanism different from $\mathrm{G} \alpha_{s}$ activation, as they did not explore directly the activation of this subunit. Therefore, the possible increase in cAMP induced by other actors different from $G \alpha_{s}$ subunits could not be discarded.

The $\mathrm{G} \alpha_{\mathrm{q} / 11}$ proteins, widely expressed through the CNS, mediate PLC activation, leading to the activation of downstream calcium signaling pathways including PKC and MAPKs activation (Sanchez-Fernandez et al., 2014). In this study, a significant stimulation of $\mathrm{G} \alpha_{\mathrm{q} / 11}$ was observed in the presence of the three cannabinoids evaluated. It has been previously reported that WIN55212-2 induces the coupling of $\mathrm{CB}_{1}$ to $\mathrm{G \alpha}_{\mathrm{q} / 11}$ in different cellular types (Lauckner et al., 2005; McIntosh et al., 2007). Our results show that not only WIN55212-2 but also $\Delta^{9}$-THC and ACEA can activate $\mathrm{G} \alpha_{\mathrm{q} / 11}$ subunit in mouse brain. Moreover, the activation of this subunit induced by $\Delta^{9}$-THC and WIN55212-2 seem to be mediated by the $\mathrm{CB}_{1}$ receptor, as demonstrate the data obtained with knockout animals. In the case of ACEA, our data suggest that ACEA modulate $\mathrm{G} \alpha_{\mathrm{q} / 11}$ through both $\mathrm{CB}_{1}$ and $\mathrm{CB}_{2}$ cannabinoid receptors.

The $\mathrm{G} \alpha_{12 / 13}$ proteins regulate important signaling events by the activation of the small GTPase protein RhoA, involved in the regulation of the actin cytoskeleton and cell motility (Kozasa et al., 2011; Yu and Brown, 2015). Under our experimental conditions, a significant stimulation of $\mathrm{G}_{12 / 13}$ subunit was observed when membranes were incubated with WIN552122 but not with $\Delta^{9}$-THC or ACEA. To our knowledge, this is the first study reporting that WIN55212-2 signals through $\mathrm{G} \alpha_{12 / 13}$ in brain cortex. These data are concordant with other studies suggesting that cannabinoids induce the stimulation of this RhoA-activator (Dalton et al., 2013; Roland et al., 2014). Moreover, our results from knockout mice show that the WIN55212-2-induced signaling through $\mathrm{G}_{12 / 13}$ in the brain seems to be mediated, mainly, by the $\mathrm{CB}_{2}$ receptor.

Although O-2050 had been described as a $\mathrm{CB}_{1}$ antagonist, it displays a complex pharmacological profile. In this context, its good affinity for $\mathrm{CB}_{2}$ receptors complicates its use as a tool 
to evaluate the unique contribution of $\mathrm{CB}_{1}$ receptor (Wiley et al., 2011). We observed that, when alone, O-2050 activated the $\mathrm{G} \alpha_{z}$ subunit. Therefore, in co-incubations, O-2050 behaved always as an antagonist of the effects of $\Delta^{9}$-THC, WIN552122 and ACEA over all the studied G $\alpha$ subunit subtypes, except for the $\mathrm{G} \alpha_{z}$ subunit. When WIN55212-2 and O-2050 were coincubated, the stimulation of $\mathrm{G} \alpha_{\mathrm{z}}$ was lower but still significant. In this way, the blockade exerted by O-2050 pharmacologically confirmed the involvement of cannabinoid receptors in the observed stimulations.

Studies in knockout mice provide very valuable data in basic research but in addition to the absence of the targeted protein, we cannot discard the appearance of putative neurodevelopmental compensatory mechanisms. In this work, we have used $\mathrm{CB}_{1}$ and/or $\mathrm{CB}_{2}$ receptor knockout mice to elucidate the role of each receptor in the observed effects of different ligands on the stimulation of $\mathrm{G} \alpha$ subunits. Moreover, Western blotting assays were carried out in order to unmask the role of a possible adaptation of cannabinoid receptors knockout mice affecting the expression level of the different $\mathrm{G} \alpha$ subtypes on the different genotypes. The observed stimulations in knockout mice may not be influenced by putative neurodevelopmental compensatory mechanisms involving $G$ proteins density. In this way, although expression of some $\mathrm{G} \alpha$ subunits in knockout mice is different from the WT, these changes do not explain the absence of stimulation in $\mathrm{CB}_{1}$ or $\mathrm{CB}_{2}$ knockout mice. The convergence of our pharmacological and genetic data demonstrate that the results obtained herein with the cannabinoid receptors knockout mice are likely due to the absence of the $\mathrm{CB}_{1}$ and/or $\mathrm{CB}_{2}$ receptors and not to non-specific changes due to neurodevelopmental adaptations.

\section{CONCLUSION}

Our results demonstrate that, in mouse brain native tissue and under our experimental conditions different exogenous cannabinoids are able to selectively activate different inhibitory and non-inhibitory $\mathrm{G} \alpha$ protein subtypes, through the activation of $\mathrm{CB}_{1}$ and/or $\mathrm{CB}_{2}$ receptors. However, it is important to be aware of potential limitations. It has been suggested that the signaling of $\mathrm{CB}_{1}$ receptors is significantly diminished in humans compared to that of rodents, a finding that may have implications for the use of rodent models for studies of $\mathrm{CB}_{1}$ receptor function related to human disease and therapy (Straiker et al., 2012).

\section{REFERENCES}

Atwood, B. K., and Mackie, K. (2010). CB2: a cannabinoid receptor with an identity crisis. Br. J. Pharmacol. 160, 467-479. doi: 10.1111/j.1476-5381.2010.00729.x

Bonhaus, D. W., Chang, L. K., Kwan, J., and Martin, G. R. (1998). Dual activation and inhibition of adenylyl cyclase by cannabinoid receptor agonists: evidence for agonist-specific trafficking of intracellular responses. J. Pharmacol. Exp. Ther. 287, 884-888.

Bosier, B., Muccioli, G. G., Hermans, E., and Lambert, D. M. (2010). Functionally selective cannabinoid receptor signalling: therapeutic implications and opportunities. Biochem. Pharmacol. 80, 1-12. doi: 10.1016/j.bcp.2010.02.013
Results of the present study may help to dissect the specific signaling pathways involved in the different pharmacological actions of cannabinoids. Moreover, the knowledge of the specific molecular target responsible of these different physiological effects will help in the design of new biased cannabinoid drugs with more specific therapeutic effect and a reduced range of adverse effects.

\section{AUTHOR CONTRIBUTIONS}

RD-A, II-L, and AL-C performed the experiments, LC, EA, AG-A, JM, and LU designed the study, JM, LC, RD-A, AG-A, and $\mathrm{LU}$ analyzed and interpreted the results, $\mathrm{RD}-\mathrm{A}$ and $\mathrm{LU}$ drafted the manuscript. All the contributors revised critically and gave their approval to the final version of the manuscript.

\section{FUNDING}

This work was supported by Plan Estatal de $\mathrm{I}+\mathrm{D}+\mathrm{i}$ 2013-2016 and Instituto de Salud Carlos III-Subdirección General de Evaluación y Fomento de la Investigación, Spanish Ministry of Economy, and FEDER (grant number PI13/01529 to LU) and the Basque Government (grant number IT616/13). II-L is a recipient of a Predoctoral Fellowship from the Basque Government. AL-C acknowledges the financial support given by Universidad de Antioquia, COLCIENCIAS through the Francisco José de Caldas fellowship $512 / 2010$.

\section{ACKNOWLEDGMENTS}

The authors would like to thank Dr. Guillermo Velasco and Dr. Ismael Galve-Roperh (Universidad Complutense de Madrid) for kindly donating $\mathrm{CB}_{1}^{-/-}$and $\mathrm{CB}_{2}^{-/-}$mice. These lines were used to set up a permanent colony and establish the $\mathrm{CB}_{1}{ }^{-/-} / \mathrm{CB}_{2}{ }^{-/-}$double knockout mouse model in our lab.

\section{SUPPLEMENTARY MATERIAL}

The Supplementary Material for this article can be found online at: http://journal.frontiersin.org/article/10.3389/fphar. 2016.00415/full\#supplementary-material

Brents, L. K., Reichard, E. E., Zimmerman, S. M., Moran, J. H., Fantegrossi, W. E., and Prather, P. L. (2011). Phase I hydroxylated metabolites of the K2 synthetic cannabinoid JWH-018 retain in vitro and in vivo cannabinoid 1 receptor affinity and activity. PLOS ONE 6:e21917. doi: 10.1371/journal.pone.00 21917

Buckley, N. E., McCoy, K. L., Mezey, E., Bonner, T., Zimmer, A., Felder, C. C., et al. (2000). Immunomodulation by cannabinoids is absent in mice deficient for the cannabinoid $\mathrm{CB}(2)$ receptor. Eur. J. Pharmacol. 396, 141-149. doi: 10.1016/S0014-2999(00)00211-9

Busnelli, M., Peverelli, E., Mantovani, G., Spada, A., and Chini, B. (2013). Deciphering the specific role of $\mathrm{G}(\mathrm{alphai} / \mathrm{o})$ isoforms: functional selective 
oxytocin ligands and somatostatin SST5 receptor mutants. Biochem. Soc. Trans. 41, 166-171. doi: 10.1042/BST20120306

Canals, M., and Milligan, G. (2008). Constitutive activity of the cannabinoid $\mathrm{CB1}$ receptor regulates the function of co-expressed $\mathrm{Mu}$ opioid receptors. J. Biol. Chem. 283, 11424-11434. doi: 10.1074/jbc.M7103 00200

Childers, S. R., Pacheco, M. A., Bennett, B. A., Edwards, T. A., Hampson, R. E., Mu, J., et al. (1993). Cannabinoid receptors: G-protein-mediated signal transduction mechanisms. Biochem. Soc. Symp. 59, 27-50.

Dalton, G. D., Peterson, L. J., and Howlett, A. C. (2013). CB(1) cannabinoid receptors promote maximal FAK catalytic activity by stimulating cooperative signalling between receptor tyrosine kinases and integrins in neuronal cells. Cell. Signal. 25, 1665-1677. doi: 10.1016/j.cellsig.2013. 03.020

De Jesus, M. L., Salles, J., Meana, J. J., and Callado, L. F. (2006). Characterization of CB1 cannabinoid receptor immunoreactivity in postmortem human brain homogenates. Neuroscience 140, 635-643. doi: 10.1016/j.neuroscience.2006.02.024

Dhopeshwarkar, A., and Mackie, K. (2016). Functional selectivity of CB2 cannabinoid receptor ligands at a canonical and noncanonical pathway. J. Pharmacol. Exp. Ther. 358, 342-351. doi: 10.1124/jpet.116.232561

Erdozain, A. M., Diez-Alarcia, R., Meana, J. J., and Callado, L. F. (2012). The inverse agonist effect of rimonabant on $G$ protein activation is not mediated by the cannabinoid CB1 receptor: evidence from postmortem human brain. Biochem. Pharmacol. 83, 260-268. doi: 10.1016/j.bcp.2011. 10.018

Fattore, L., Spano, M. S., Cossu, G., Deiana, S., and Fratta, W. (2003). Cannabinoid mechanism in reinstatement of heroin-seeking after a long period of abstinence in rats. Eur. J. Neurosci. 17, 1723-1726. doi: 10.1046/j.1460-9568.2003. 02607.x

Gettys, T. W., Sheriff-Carter, K., Moomaw, J., Taylor, I. L., and Raymond, J. R. (1994). Characterization and use of crude alpha-subunit preparations for quantitative immunoblotting of $\mathrm{G}$ proteins. Anal. Biochem. 220, 82-91. doi: 10.1006/abio.1994.1302

Glass, M., and Northup, J. K. (1999). Agonist selective regulation of G proteins by cannabinoid $\mathrm{CB}(1)$ and $\mathrm{CB}(2)$ receptors. Mol. Pharmacol. 56, 1362-1369.

Gonzalez-Maeso, J., Rodriguez-Puertas, R., Gabilondo, A. M., and Meana, J. J. (2000). Characterization of receptor-mediated [35S]GTPgammaS binding to cortical membranes from postmortem human brain. Eur. J. Pharmacol. 390, 25-36. doi: 10.1016/S0014-2999(99)00827-4

Hillard, C. J., Manna, S., Greenberg, M. J., DiCamelli, R., Ross, R. A., Stevenson, L. A., et al. (1999). Synthesis and characterization of potent and selective agonists of the neuronal cannabinoid receptor (CB1). J. Pharmacol. Exp. Ther. 289, 1427-1433.

Hinton, D. R., Blanks, J. C., Fong, H. K., Casey, P. J., Hildebrandt, E., and Simons, M. I. (1990). Novel localization of a $G$ protein, Gz-alpha, in neurons of brain and retina. J. Neurosci. 10, 2763-2770.

Howlett, A. C., Barth, F., Bonner, T. I., Cabral, G., Casellas, P., Devane, W. A., et al. (2002). International union of pharmacology. XXVII. Classification of cannabinoid receptors. Pharmacol. Rev. 54, 161-202. doi: 10.1124/pr.54. 2.161

Hudson, B. D., Hebert, T. E., and Kelly, M. E. (2010). Physical and functional interaction between CB1 cannabinoid receptors and beta2adrenoceptors. Br. J. Pharmacol. 160, 627-642. doi: 10.1111/j.1476-5381.2010. 00681.x

Khajehali, E., Malone, D. T., Glass, M., Sexton, P. M., Christopoulos, A., and Leach, K. (2015). Biased agonism and biased allosteric modulation at the CB1 cannabinoid receptor. Mol. Pharmacol. 88, 368-379. doi: 10.1124/mol.115.099192

Kozasa, T., Hajicek, N., Chow, C. R., and Suzuki, N. (2011). Signalling mechanisms of RhoGTPase regulation by the heterotrimeric $G$ proteins $\mathrm{G} 12$ and G13. J. Biochem. 150, 357-369. doi: 10.1093/jb/mvr105

Lauckner, J. E., Hille, B., and Mackie, K. (2005). The cannabinoid agonist WIN55,212-2 increases intracellular calcium via CB1 receptor coupling to Gq/11 G proteins. Proc. Natl. Acad. Sci. U.S.A. 102, 19144-19149. doi: $10.1073 /$ pnas.0509588102
Mackie, K. (2005). Distribution of cannabinoid receptors in the central and peripheral nervous system. Handb. Exp. Pharmacol. 168, 299-325. doi: 10.1007/3-540-26573-2_10

Makwana, R., Molleman, A., and Parsons, M. E. (2010). Evidence for both inverse agonism at the cannabinoid $\mathrm{CB} 1$ receptor and the lack of an endogenous cannabinoid tone in the rat and guinea-pig isolated ileum myenteric plexus-longitudinal muscle preparation. Br. J. Pharmacol. 160, 615626. doi: 10.1111/j.1476-5381.2010.00717.x

Marsicano, G., Wotjak, C. T., Azad, S. C., Bisogno, T., Rammes, G., Cascio, M. G., et al. (2002). The endogenous cannabinoid system controls extinction of aversive memories. Nature 418, 530-534. doi: 10.1038/nature 00839

McIntosh, B. T., Hudson, B., Yegorova, S., Jollimore, C. A., and Kelly, M. E. (2007). Agonist-dependent cannabinoid receptor signalling in human trabecular meshwork cells. Br. J. Pharmacol. 152, 1111-1120. doi: 10.1038/sj.bjp.07 07495

Milligan, G., and Kostenis, E. (2006). Heterotrimeric G-proteins: a short history. Br. J. Pharmacol. 147(Suppl. 1), S46-S55. doi: 10.1038/sj.bjp.07 06405

Minetti, G. C., Feige, J. N., Bombard, F., Heier, A., Morvan, F., Nurnberg, B., et al. (2014). Galphai2 signalling is required for skeletal muscle growth, regeneration, and satellite cell proliferation and differentiation. Mol. Cell. Biol. 34, 619-630. doi: 10.1128/MCB.00957-13

Panagis, G., Mackey, B., and Vlachou, S. (2014). Cannabinoid regulation of brain reward processing with an emphasis on the role of $\mathrm{CB1}$ receptors: a step back into the future. Front. Psychiatry 5:92. doi: 10.3389/fpsyt.2014. 00092

Pertwee, R. G., Howlett, A. C., Abood, M. E., Alexander, S. P., Di Marzo, V., Elphick, M. R., et al. (2010). International union of basic and clinical pharmacology. LXXIX. Cannabinoid receptors and their ligands: beyond $\mathrm{CB}(1)$ and $\mathrm{CB}(2)$. Pharmacol. Rev. 62, 588-631. doi: 10.1124/pr.110.0 03004

Plummer, N. W., Spicher, K., Malphurs, J., Akiyama, H., Abramowitz, J., Nurnberg, B., et al. (2012). Development of the mammalian axial skeleton requires signalling through the Galpha(i) subfamily of heterotrimeric G proteins. Proc. Natl. Acad. Sci. U.S.A. 109, 21366-21371. doi: 10.1073/pnas.1219810110

Prather, P. L., Martin, N. A., Breivogel, C. S., and Childers, S. R. (2000). Activation of cannabinoid receptors in rat brain by WIN 55212-2 produces coupling to multiple $\mathrm{G}$ protein alpha-subunits with different potencies. Mol. Pharmacol. 57, 1000-1010.

Presley, C. S., Abidi, A. H., and Moore, B. M. II. (2016). Cannabinoid receptor 1 ligands revisited: Pharmacological assessment in the ACTOne system. Anal. Biochem. 498, 8-28. doi: 10.1016/j.ab.2015.12.019

Rinaldi-Carmona, M., Calandra, B., Shire, D., Bouaboula, M., Oustric, D., Barth, F., et al. (1996). Characterization of two cloned human CB1 cannabinoid receptor isoforms. J. Pharmacol. Exp. Ther. 278, 871-878.

Roland, A. B., Ricobaraza, A., Carrel, D., Jordan, B. M., Rico, F., Simon, A., et al. (2014). Cannabinoid-induced actomyosin contractility shapes neuronal morphology and growth. Elife 3: e03159. doi: 10.7554/eLife.03159

Rubino, T., and Parolaro, D. (2016). The impact of exposure to cannabinoids in adolescence: insights from animal models. Biol. Psychiatry 79, 578-585. doi: 10.1016/j.biopsych.2015.07.024

Sanchez-Fernandez, G., Cabezudo, S., Garcia-Hoz, C., Beninca, C., Aragay, A. M., Mayor, F., et al. (2014). Galphaq signalling: the new and the old. Cell. Signal. 26, 833-848. doi: 10.1016/j.cellsig.2014.01.010

Shapira, M., Vogel, Z., and Sarne, Y. (2000). Opioid and cannabinoid receptors share a common pool of GTP-binding proteins in cotransfected cells, but not in cells which endogenously coexpress the receptors. Cell. Mol. Neurobiol. 20, 291-304. doi: 10.1023/A:1007058008477

Sternweis, P. C., and Robishaw, J. D. (1984). Isolation of two proteins with high affinity for guanine nucleotides from membranes of bovine brain. J. Biol. Chem. 259, 13806-13813.

Straiker, A., Wager-Miller, J., Hutchens, J., and Mackie, K. (2012). Differential signalling in human cannabinoid $\mathrm{CB} 1$ receptors and their splice variants in autaptic hippocampal neurones. Br. J. Pharmacol. 165, 2660-2671. doi: 10.1111/j.1476-5381.2011.01744.x 
Valdizan, E. M., Castro, E., and Pazos, A. (2010). Agonist-dependent modulation of G-protein coupling and transduction of 5-HT1A receptors in rat dorsal raphe nucleus. Int. J. Neuropsychopharmacol. 13, 835-843. doi: $10.1017 /$ S1461145709990940

Wiley, J. L., Breivogel, C. S., Mahadevan, A., Pertwee, R. G., Cascio, M. G., Bolognini, D., et al. (2011). Structural and pharmacological analysis of O-2050, a putative neutral cannabinoid $\mathrm{CB}(1)$ receptor antagonist. Eur. J. Pharmacol. 651, 96-105. doi: 10.1016/j.ejphar.2010.10.085

Yu, O. M., and Brown, J. H. (2015). G protein-coupled receptor and RhoAstimulated transcriptional responses: links to inflammation, differentiation, and cell proliferation. Mol. Pharmacol. 88, 171-180. doi: 10.1124/mol.115.097857
Conflict of Interest Statement: The authors declare that the research was conducted in the absence of any commercial or financial relationships that could be construed as a potential conflict of interest.

Copyright (c) 2016 Diez-Alarcia, Ibarra-Lecue, Lopez-Cardona, Meana, GutierrezAdán, Callado, Agirregoitia and Urigüen. This is an open-access article distributed under the terms of the Creative Commons Attribution License (CC BY). The use, distribution or reproduction in other forums is permitted, provided the original author(s) or licensor are credited and that the original publication in this journal is cited, in accordance with accepted academic practice. No use, distribution or reproduction is permitted which does not comply with these terms. 